Article

\title{
Antibacterial, Antibiofilm and Anticancer Activity of Biologically Synthesized Silver Nanoparticles Using Seed Extract of Nigella sativa
}

\author{
Ahmad Almatroudi ${ }^{1, *}$, Habeeb Khadri ${ }^{1}$, Mohd Azam ${ }^{1}$, Arshad Husain Rahmani ${ }^{1}$, \\ Fahd Khaleefah Al Khaleefah ${ }^{2}$, Riazunnisa Khateef ${ }^{3, *}$, Mohammad Azam Ansari 4 (D) and \\ Khaled S. Allemailem ${ }^{1}$ (D) \\ 1 Department of Medical Laboratories, College of Applied Medical Sciences, Qassim University, Qassim 51452, \\ Saudi Arabia; kdry@qu.edu.sa (H.K.); m.aftab@qu.edu.sa (M.A.); ah.rahmani@qu.edu.sa (A.H.R.); \\ k.allemailem@qu.edu.sa (K.S.A.) \\ 2 Infection Prevention and control Department, Al Rass General Hospital, Al Qassim 58867, Saudi Arabia; \\ fkalkhaleefah@moh.gov.sa \\ 3 Departments of Biotechnology and Bioinformatics, Yogi Vemana University, Kadapa 516005, AP, India \\ 4 Department of Epidemic Disease Research, Institutes of Research and Medical Consultations (IRMC), \\ Imam Abdulrahman Bin Faisal University, Dammam 31441, Saudi Arabia; maansari@iau.edu.sa \\ * Correspondence: aamtrody@qu.edu.sa (A.A.); krbtbi@yogivemanauniversity.ac.in (R.K.)
}

Received: 2 March 2020; Accepted: 20 March 2020; Published: 26 March 2020

\begin{abstract}
Silver nanoparticle (AgNP) based approaches using plant materials have been accepted as biomedical applications. The current study aimed to test the antibacterial, antibiofilm, and anticancer activity of silver nanoparticles synthesized by seed extract of Nigella sativa (Ns) as stabilizing and reducing agents. Characterization was done through UV-visible spectroscopy, X-ray diffraction (XRD), Fourier transform infrared (FTIR) spectroscopy, scanning electronic microscopy (SEM), and transmission electronic microscopy (TEM) analyses. UV-Vis spectroscopy showed a specific silver plasmon peak at $400 \mathrm{~nm}$ and a quick color change was observed in the bio-reaction medium. Electron microscopic images of Ns-AgNPs identified as spherical in shape with varied size ranged between 8 and $80 \mathrm{~nm}$ and zeta potential analysis evidenced the particles stability and polydisperity. Antibiofilm activity of Ns-AgNPs was evident as at $12.5 \mu \mathrm{g} / \mathrm{mL}$ Ns-AgNps restricted the biofilm formation by $88.42 \%$ for Enterococcus faecalis, $84.92 \%$ for E. coli, $81.86 \%$ for Klebsiella pneumonia, $82.84 \%$ for Staphylococcus aureus, and $49.9 \%$ for Pseudomonas aeruginosa, respectively. Furthermore, biologically synthesized AgNPs showed the significant bacteriostatic and bactericidal activity. Even the lowest concentration of Ns-AgNps restricted the highest rate of inhibition against $S$. aureus (6.5 and $15 \mu \mathrm{g} / \mathrm{mL}$ ) and E. faecalis ( 6.5 and $15 \mu \mathrm{g} / \mathrm{mL}$ ). Antimicrobial activity of $S$. aureus and E. fecalis was more prominent than E. coli (15 and $30 \mu \mathrm{g} / \mathrm{mL}$ ), K. pneumonia (15 and $30 \mu \mathrm{g} / \mathrm{mL}$ ) and P. aeruginosa ( 30 and $60 \mu \mathrm{g} / \mathrm{mL}$ ) respectively. Moreover, Ns-AgNPs revealed significant cytotoxic ability and substantially killed human breast cancer cell (HCC-712) viability. The results of current study advocate that Ns-AgNps may be considered as a potential option in biomedical applications, alternative therapy, designing anti-biofilm agents, treating multi drug resistance bacterial infection, and anti-cancer therapy.
\end{abstract}

Keywords: anti-biofilm; anti-cancer; HCC-712 cell lines; Nigella sativa; silver nanoparticle

\section{Introduction}

Currently, modern research in the nanoscience and technology fields are developing rapidly and attracting attention worldwide. In the interest of bio-nanomaterial synthesis, such as gold, copper, platinum, and silver, due to its peculiar design and synthesis process, those metal 
nanoparticles ranging between 1 and 100 nanometers have drawn great attention towards potential applications in multi-disciplinary areas such as biomedicine, environment, biotechnology, drug delivery, and nanomedicine [1]. Physical and chemical methods for the synthesis of metal nanoparticles are limited because of its costly equipment's, toxicity, and environmental damage [2]. Currently, green-approach technology is attracting consideration due to its being a biogenic, non-toxic, and cheap approach that has become a central focusing area of research, leading to explore various types of bio-reducing agents. Many researchers reported that microbes, plants and their products, such as Ananas comosus (L.), Cynara scolymus, Oscillatoria limnetica, and Phoenix sylvestris L., have been used as bio-reducing agents [3-6] to design and manipulate the metal particles for acquiring unique shape and size.

The constantly increasing antibiotic resistance in clinical strains is a serious concern to global health sector that needs an urgent action. Therefore, discovering the new substitutes to the presently applied antibiotics has become an essential task. Nayak et al synthesized crystalline and spherical AgNPs using bark extracts showedantibacterial activity against gram-positive and -negative bacteria [7]. However, silver nanoparticles have been utilized in various sectors mainly in health and medicine industry because of its excellent antimicrobial properties [8]. The biofilm formation is a critical method applied by different pathogenic bacteria to stay lively in environment. Biofilm forming microbes can cause numerous serious infections such as eye, skin, wound urinary and heart leading high mortality and morbidity due to biomedical devices [9]. Traditional treatment for bacterial infection is commonly based on bactericidal or bacterial static agents. Some pathogens showed protection against drugs due to the development of biofilm. Furthermore, in the virulence of various pathogenic microbes, biofilms play a vital role as well. In these circumstances, the bioscience and pharmaceutical applications have been revolutionized due to the discovery of new biocide targeting biofilm [10]. According to the National Institute of Health (NIH), approximately sixty percent of microbial infections have been found to be association of biofilm. Various biofilm associated bacteria have proven ineffective to chemical disinfectants, germicides, and antibiotics [11].

All over the world, women breast cancer has grown an immense concern, particularly with treatment procedures which can cause adverse side effects [12]. Nowadays, different types of cancer are spreading day by day, so there is an immediate requirement to discover and identify new anticancer drugs with less side effects on the immune system [13]. In spite of various attempts, chemotherapy of cancerous cells is not fully successful due to multi drug resistance [14]. However, silver nanoparticles have been demonstrated for potential role in anticancer activity [15].

Black seed is indigenous to North Africa, Southwest Asia, and Southern Europe and it is farmed in many countries like Saudi Arabia, Middle Eastern Mediterranean region, India, Pakistan, South Europe, Turkey, Syria. Nigella sativa posesses therapeutic potential and biological activities and it acquires broad spectrum of activities such as antioxidant, diuretic, antidiabetic, antihypertensive, anticancer, antimicrobial, immunomodulatory, anti-schistosomiasis, anti-inflammatory, analgesics, bronchodilator, spasmolytic, hepatoprotective, gastro protective, and renal protective [16]. Nigella sativa oil is multipurpose product with nutritional and medicinal properties [17]. Several studies have shown the application of AgNPs in different fields, but scanty reports are available to exhibit the role of AgNPs as anti-biofilm activity as well as anti-cancerous activity. The aim of the current study was (i) biosynthesis of AgNps using seed extract of Nigella sativa, (ii) characterization of prepared AgNPs by different sophisticated techniques, (iii) investigation of antibacterial and anti-biofilm potential of synthesized AgNPs against different bacterial strains for biomedical application, and (iv) evaluation of the cytotoxic effect of biosynthesized AgNPs on human breast cancer (HCC-712) cell line for therapeutic application in the treatment of breast cancer. 


\section{Material and Methods}

\subsection{Bacterial Strains, Culture Media, Seeds and Chemicals}

Nigella sativa seeds (Ns) were obtained from a local market, Qassim, Saudi Arabia. Analytical grade Silver nitrate $\left(\mathrm{AgNO}_{3}\right)$, were procured from Sigma- Aldrich Company. Breast cancer cell line (HCC712) was acquired from National Centre for Cell Science (NCCS), Pune, India. Other reagents and culture Medias were bought from Hi-Media, India. Bacterial cultures of K. pneumoniae (MTCC 618), E. coli (MTCC 40), S. aureus (MTCC 3160), P. aeruginosa (MTCC 1688) and E. faecalis (MTCC 439) were obtained from Institute of microbial technology, IMTECH, Chandigarh, India.

\subsection{Preparation of Aqueous Nigella Sativa Seed Extract}

Briefly, $2.5 \mathrm{~g}$ of Nigella Sativa seed powder was dissolved in $100 \mathrm{~mL}$ of distilled water in a conical flask. The solution was boiled at $70-80{ }^{\circ} \mathrm{C}$ for $15-20 \mathrm{~min}$. in a water bath. Solution was filtered at room temperature and stored at $4{ }^{\circ} \mathrm{C}$ for further analysis as previously done by Kuppuswamy et al. [18].

\subsection{Biosynthesis of Silver Nanoparticles from Nigella Sativa}

Biogenic AgNps were amalgamated by adding $10 \mathrm{~mL}$ of seed extract to $90 \mathrm{~mL}$ of $0.1 \mathrm{mM} \mathrm{AgNO}$. The solution obtained was kept in dark condition to avoid auto-oxidation of silver.

\subsection{Isolation and Purification of AgNPs}

After synthesis the reaction mixture was sequentially centrifuged at $8000 \mathrm{rpm}$ and $5000 \mathrm{rpm}$ for $10 \mathrm{~min}$ by replacing supernatant with distilled water every time. The pellet form of silver nanoparticles was dried up at $60^{\circ} \mathrm{C}$ in hot air oven and was finally diluted in $1 \%$ dimethyl sulfoxide (DMSO). The biosynthesized AgNps was stored and employed for further characterization process.

\subsection{Characterization of Synthesized Ns-AgNps}

The reduction of $\mathrm{Ag}+$ ions was observed and recorded by using UV-Vis spectrophotometer (Lambda 35, Perkin-Elmer, USA) at various time intervals in the range of 300 to $800 \mathrm{~nm}$. Fourier transform infrared spectroscopy (FTIR) was utilized to identify the presence of possible biomolecules or functional groups in the aqueous seed extract of Nigella sativa, which are accountable for the reduction of the Ag+ ions and capping of AgNPin the range of 400 to $4000 \mathrm{~cm}^{-1}$ at a resolution of $4 \mathrm{~cm}^{-1}$ at $25^{\circ} \mathrm{C}$ using FTIR-Perkin Elmer Spectrum Two model, UK. The X-ray diffraction patterns of the AgNP samples were examined by using XRD-Smart Lab (9kW)-RIKAGU, Japan). The size and morphology of the prepared Ag NPs from the seed extracts were examined by transmission electron microscopy (TEM) JEOL JEM2100 and Scanning electron microscopy JEOL JSM 5500. Dynamic light scattering (DLS) (Zetasizer Nano ZS, Japan) were used to examine the nanoparticle size distribution with measuring and recording the zeta potential.

\subsection{Assessment of Minimum Inhibitory Concentrations (MICs) and Minimum Biocidal Concentration (MBCs) Activity}

To evaluate the antibacterial activity of Ns-AgNps, it was tested against the bacterial strains such as K. pneumoniae (MTCC 618), E. coli (MTCC 40), S. aureus (MTCC 3160), P. aeruginosa (MTCC 1688), and E. faecalis (MTCC 439).

MIC values of synthesized AgNPs against different bacteria strains were examined by using protocol described by Ansari et al [19]. Briefly, all the bacterial strains were cultured firstly on blood agar plates at $37^{\circ} \mathrm{C}$ for overnight and then next day single colony was inoculated into the tryptic soy broth(TSB) for $5-6 \mathrm{~h}$ at $37^{\circ} \mathrm{C}$ on rotor shaker with $100 \mathrm{rpm}$ to get the bacterial growth of $10^{5}$ to $10^{6}\left(\mathrm{CFU}_{\mathrm{S}} / \mathrm{mL}\right)$ for each standard strains. The Ns-AgNPs were serially diluted with different concentrations $(6.5-100 \mu \mathrm{g} / \mathrm{mL})$. Then, $20 \mu \mathrm{L}$ of bacterial culture of each strain was added into $180 \mu \mathrm{L}$ 
TSB and then kept incubator at $37^{\circ} \mathrm{C}$ for $24 \mathrm{~h}$, and optical density was measured at $550 \mathrm{~nm}$. The lowest concentration of AgNPs which restricted the $99 \%$ of bacterial growth was considered as MIC. Further to determine the MBC value, $100 \mu \mathrm{L}$ bacterial inoculums were streaked on the agar plate from the $\mathrm{MIC}$ tubes and incubated at $37^{\circ} \mathrm{C}$ for overnight. The lowest concentration of Ns-AgNps at which no bacterial growth was seen on inoculated agar plate has been considered as MBC.

\subsection{Detection of Anti-Biofilm Activity}

The anti-biofilm activity of biosynthesized Ns-AgNPs was observed against the biofilm producing standard bacterial strains with or without Ns-AgNPs. Biofilm production of the concerned pathogenic bacteria was carried out using the tissue culture plate (TCP) method as explained by Balasamy et al. [20], which is commonly applied worldwide and considered as standard test for detection of biofilm production with some modifications. MTCC bacterial strains of K. pneumonia, E. coli, S. aureus, $P$. aeruginosa, and E. faecalis were grown on blood agar plate for overnight at $37{ }^{\circ} \mathrm{C}$ and the next day a single colony of all bacteria were inoculated into different conical flasks containing the $100 \mathrm{~mL}$ TSB at $37^{\circ} \mathrm{C}$ for $6-7 \mathrm{~h}$ with shaking at $100 \mathrm{rpm}$ until to obtain approximately $2.5 \times 10^{8} \mathrm{CFUs} / \mathrm{mL}$. These bacterial inoculums were further diluted (1:100) with fresh TSB medium to approximately $10^{6} \mathrm{CFUs} / \mathrm{mL}$ and transferred it to 96 wells flat bottom TCPs and incubated at $37^{\circ} \mathrm{C}$ for overnight. After completing the incubation, the old culture medium was changed with a fresh TSB medium including different concentrations of Ns-AgNPs $(6.5-100 \mu \mathrm{g} / \mathrm{mL})$, without disrupting the biofilm. Samples with AgNPs were incubated further at $37^{\circ} \mathrm{C}$ for $24 \mathrm{~h}$. Thereafter, the medium was discarded; each well were gently washed two times with sterile 1x Phosphate buffer saline (PBS) to get rid of the planktonic state or free floating bacteria and dried it at room temperature for $20 \mathrm{~min}$. $0.1 \%$ crystal violet solution was added to each well for $15 \mathrm{~min}$ to stain the biofilms. The surplus stain was eliminated by washing three times with sterile 1\% PBS, and dried at room temperature for $30 \mathrm{~min} .100 \mathrm{~mL}$ of 95\% ethanol was then added to each well. Optical densities (OD) of stained acquired biofilm were observed by a micro ELISA reader at wavelength $595 \mathrm{~nm}$. Experiments were repeated in triplicate. Average OD values of sterile medium were measured and deducted from the all test values. [21]. The OD of sample was converted to percentage of biofilm inhibition, calculated as follows:

Percentage of biofilm $=$ OD of the test/OD of the control $\times 100$

\subsection{Determination of In Vitro Anticancer Activity of Synthesized AgNPs}

\subsubsection{Cell Culture and Cell Line Maintenance}

Breast cancer cell line (HCC712) was acquired from National Centre for Cell Science (NCCS), Pune, India. The HCC712 cells were freshly cultivated as monolayer in Dulbecco's Modified Eagles's Medium (DMEM), supplemented with 10\% FBS, 1\% glutamine, and $100 \mathrm{U} / \mathrm{mL}$ penicillin/streptomycin and incubated at $37^{\circ} \mathrm{C}$ in $5 \% \mathrm{CO}_{2}$ atmosphere. It was grown in a $75 \mathrm{~cm}^{2}$ tissue culture flask.

\subsubsection{Cell Viability Test}

The colorimetric MTT assay was applied to scrutinize the cytotoxic effects. The activity of Ns-AgNPs was examined against HCC712 cell lines $\left(1 \times 10^{6}\right.$ cells $\left./ \mathrm{mL}\right)$ and the culture was seeded in 96 flat-bottom well plate that was suitable for high throughput screening. Different concentrations ( 25 to $200 \mu \mathrm{g} / \mathrm{mL}$ ) of silver nanoparticles were added to the cultures and incubated for $24 \mathrm{~h}$ in $5 \%$ $\mathrm{CO}_{2}$ atmosphere. After $24 \mathrm{~h}$, the cells were washed with PBS followed by mixing of $100 \mu \mathrm{L}$ of MTT, and the cells were again incubated for $3-4 \mathrm{hr}$ at $37^{\circ} \mathrm{C}$ in $5 \% \mathrm{CO}_{2}$ atmosphere. The formazan crystals were suspended in $200 \mu \mathrm{L}$ of DMSO and optical density of each well was observed. The quantity of formazan product as measured in the calorimetric assay at $570 \mathrm{~nm}$ with a reference filter at $630 \mathrm{~nm}$ determined and the growth inhibition rates were calculated as a percentage. Growth inhibition $=\mathrm{A} 570$ of treated cells/A570 of control cells $\times 100$. 


\subsubsection{Measurement of Cytomorphological Changes in HCC712}

After the adequate growth of HCC712 cells in tissue culture flask, it was treated with different concentrations of Ns-AgNPs and then incubated for $24 \mathrm{~h}$ at $37^{\circ} \mathrm{C}$ in $5 \% \mathrm{CO}_{2}$ atmosphere. After the incubation, the gross morphological changes in the cells were examined by bright field microscopy.

\subsection{Statistical Analysis}

All antibacterial and cytotoxic activities were performed with minimum of three replicates. Means, standard deviations, error bars were calculated using Microsoft excel. The error bars are given for each bar showing a $95 \%$ confidence interval.

\subsection{Ethics Statement}

As this experiment was totally based on in-vitro study using bacterial isolates to evaluate the anti-microbial and anti-biofilm activity of black seed silver nanoparticle, ethical review is not required.

\section{Results and Discussion}

The synthesis of Ns-AgNPs was primarily authenticated visually and then by using UV-visible spectroscopy which has been commonly applied to characterize the synthesized metal nanoparticles. After mixing the silver nitrate into the homogenized extract, a change in colour from pale yellow to tan-brownish colour was observed due to a surface plasmon resonance phenomenon, which confirmed the formation of AgNPs in the reaction mixture.

\subsection{UV-Vis Spectrum}

UV-Vis spectroscopy is one of the best applicable tools to confirm the formation of AgNPs. Moreover, surface plasmon resonance (SPR) patterns are frequently utilized as suggestive tools for metal nanoparticles formation as SPR depends on a number of parameters, including size and medium dielectric constant [22]. The maximum absorption spectrum was determined between 300-800 nm (Figure 1). Moreover, characteristic peak at $400 \mathrm{~nm}$ in the UV-Vis spectrum was observed and this study specifically provides evidence of formation of biosynthesized silver nanoparticles from Nigella sativa seeds extract (Figure 1). This result is in consistent with the previous study, which exhibited that the synthesis of silver nanoparticles from Phoenix dactylifera (date palm) seeds and recorded the plasma resonance peak at $459 \mathrm{~nm}$ [11]. In this context, another study result revealed that a reduction of silver ions was observed between 300 and $600 \mathrm{~nm}$ and peak absorption was monitored at $440 \mathrm{~nm}$ by UV-Vis spectroscopy [23].

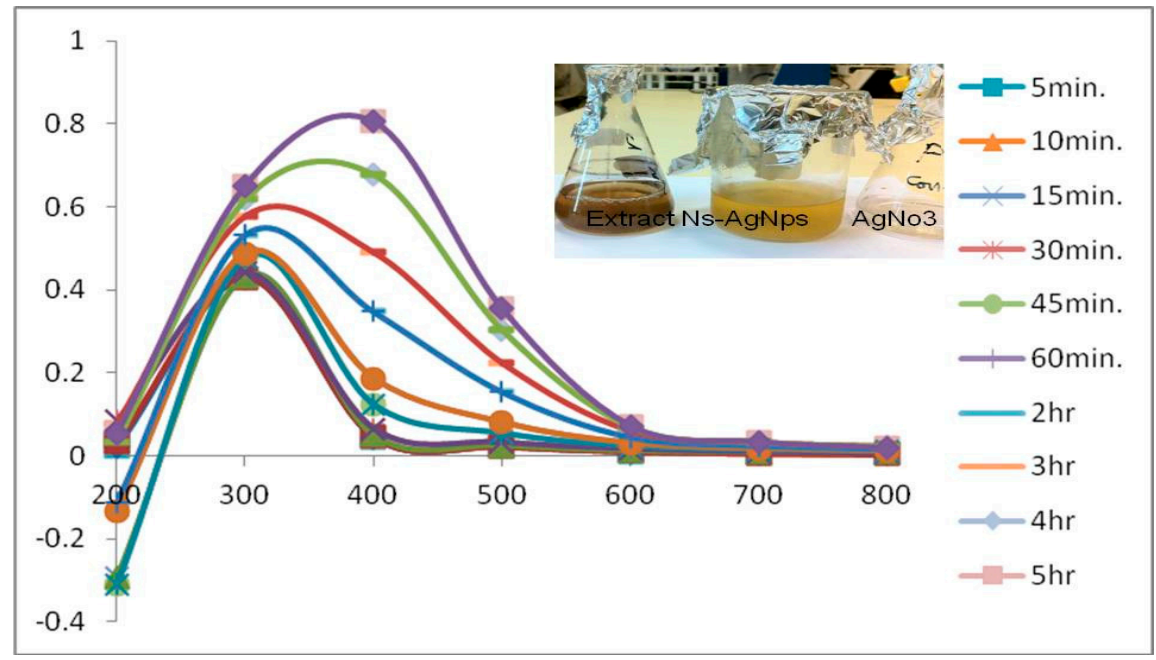

Figure 1. UV absorption spectrum of the AgNPs synthesized from Nigella sativa seed extract (Inset: Change of color from dark brownto light golden yellow). 


\subsection{FTIR Spectroscopy}

FTIR spectroscopy, an analytical technique, was employed to discover the biomolecules of Nigella sativa seeds extract that were bound particularly on the synthesized AgNPs. FTIR results (Figure 2A) for Nigella sativa showed the compounds responsible for the synthesis of AgNPs. FTIR spectroscopy was scanned at a range $400-4000 \mathrm{~cm}^{-1}$ of resolution to ensure the formation of silver nanoparticles. Bands were observed at 3421.30, 2923.92, 2350.08, 1019.06, 666.76, and $2926 \mathrm{~cm}^{-1}$. The bands at 3421.30 and $2923.92 \mathrm{~cm}^{-1}$ demonstrated the reduction of silver ions in NPs. The band at $1019.06 \mathrm{~cm}^{-1}$ showed the N-H bonding vibrate of amides. The band in seed extract at 1019.06 to $666.76 \mathrm{~cm}^{-1}$ after the bio reduction of AgNP's pointed out the $\mathrm{C}=\mathrm{C}$ stretching mode in the aromatic compounds which validated the presence of aromatic compounds like flavonoids. The peaks observed at the $605 \mathrm{~cm}^{-1}$ confirms the C-S stretch (Figure 2B).

This finding was supported by the previous findings that were conducted on different plant extract [24-26]. In this regard, silver nanoparticle using garlic extract reported stretching peaks at 3270 and $2930 \mathrm{~cm}^{-1}$, probably belonging to $-\mathrm{O}-\mathrm{H}$ and $-\mathrm{C}-\mathrm{H}$ peaks, correspondingly, which match to sugars in the garlic extract. Furthermore, it is identified that garlic hold sugars including sucrose and fructose, which play role as reducing and stabilizing agents [27]. So, based on finding FTIR results confirmed that biomolecules and some proteins are present in the extract sample to protect it from further changes and responsible for capping, stabilization and reduction of $\mathrm{Ag}^{+}$to $\mathrm{AgNPs}$.

\subsection{X-ray Diffraction Analysis}

XRD analysis was performed to examine the crystalline characteristics of the biosynthesized AgNPs produced by the seed of Nigella sativa seeds extract. The X-ray diffraction pattern of the biosynthesized AgNPs procured by the seed of Nigella sativa extract was determined at $29.18^{\circ}, 34.18^{\circ}$, $39.45^{\circ}, 47.18^{\circ}$ and can be indexed to the angle values of (111), (200), (220), (240) crystalline planes of cubic silver (Figure 2C). The diffraction pattern result based on Nigella sativa extract established the formation of particles was nano in size, crystalline and stable in nature. In this sense, similar observations with biosynthesized nanoparticles have been demonstrated [28,29]. XRD data and The Scherrer equation was used to calculate the average size of Ag nanoparticles from extract [30].

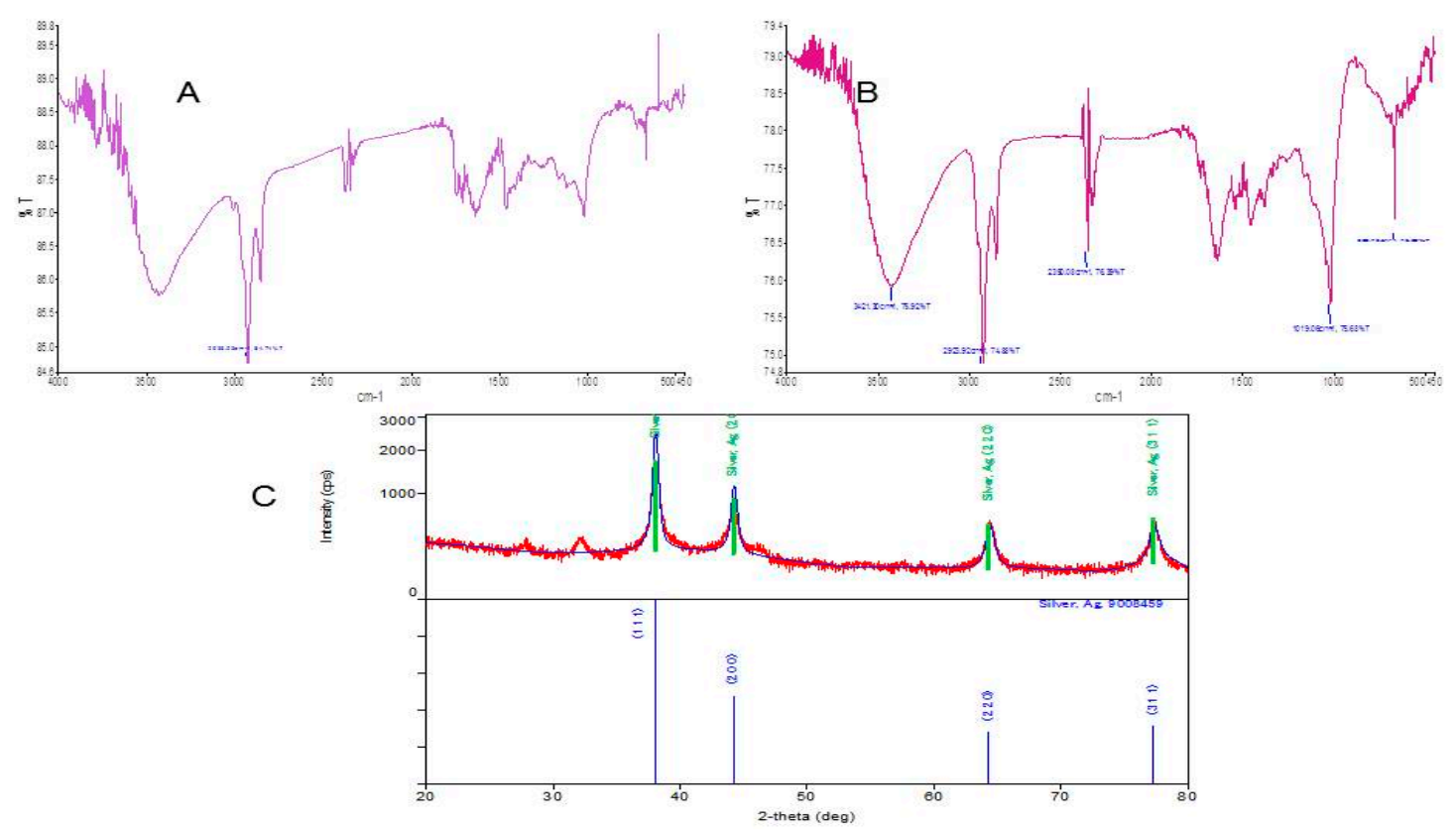

Figure 2. (A) FTIR spectrum of Nigella sativa seed extract (B) FTIR spectrum of AgNp's (C) XRD spectrum of AgNp's of Nigella Sativa. 


\subsection{SEM and TEM Analysis}

SEM analysis was done to check the dimensions and shape of the nanoparticles. The AgNPs synthesized from Nigella sativa were of uniform size disseminated evenly and spherical in shape (Figure 3A,B). The result of SEM analysis of biosynthesized silver nanoparticles from extract was obviously differentiable due to their size difference. The current results were in accordance with that of Otunola et al. justified the similar range of Ag NPs from pepper and garlic [31]. EDX technique was used to observe the elemental composition of biosynthesized Ag nanoparticles in solution. In X-ray spectrum, all the elements showed a unique set of peaks with different atomic structure as shown in (Figure 3C). Meanwhile, silver metal exhibited a strong signal in EDX image and weight percent $40 \%$ clearly indicated the presence of metallic silver nanocrystals (Figure 3C,D).

The most appropriate microscopic technique to investigate the size and morphology of AgNPs is TEM [32]. TEM was used to determine the biosynthesized AgNPs (Appendix A) in nanoscale from extract. TEM analysis confirmed the presence of AgNPs in the sample of N. sativa average size ranging between 8 and $80 \mathrm{~nm}$, smaller size of particle good indicator for effective performance and quality of AgNPs (Figure 4A,B). The previous report also showed that the AgNPs obtained from seed extract of Phoenix dactylifera were mostly spherical in shape and similar sizes ranging [33]. Another pioneer study result revealed that TEM image of AgNPs were found similar shape and with narrow distribution [34]. DLS was also used to investigate the particle size distribution, and revealed the particle size 8-80 nm with average particle size $55 \mathrm{~nm}$, as shown in (Figure 4C). Similar size distribution studies have been reported previously [33].
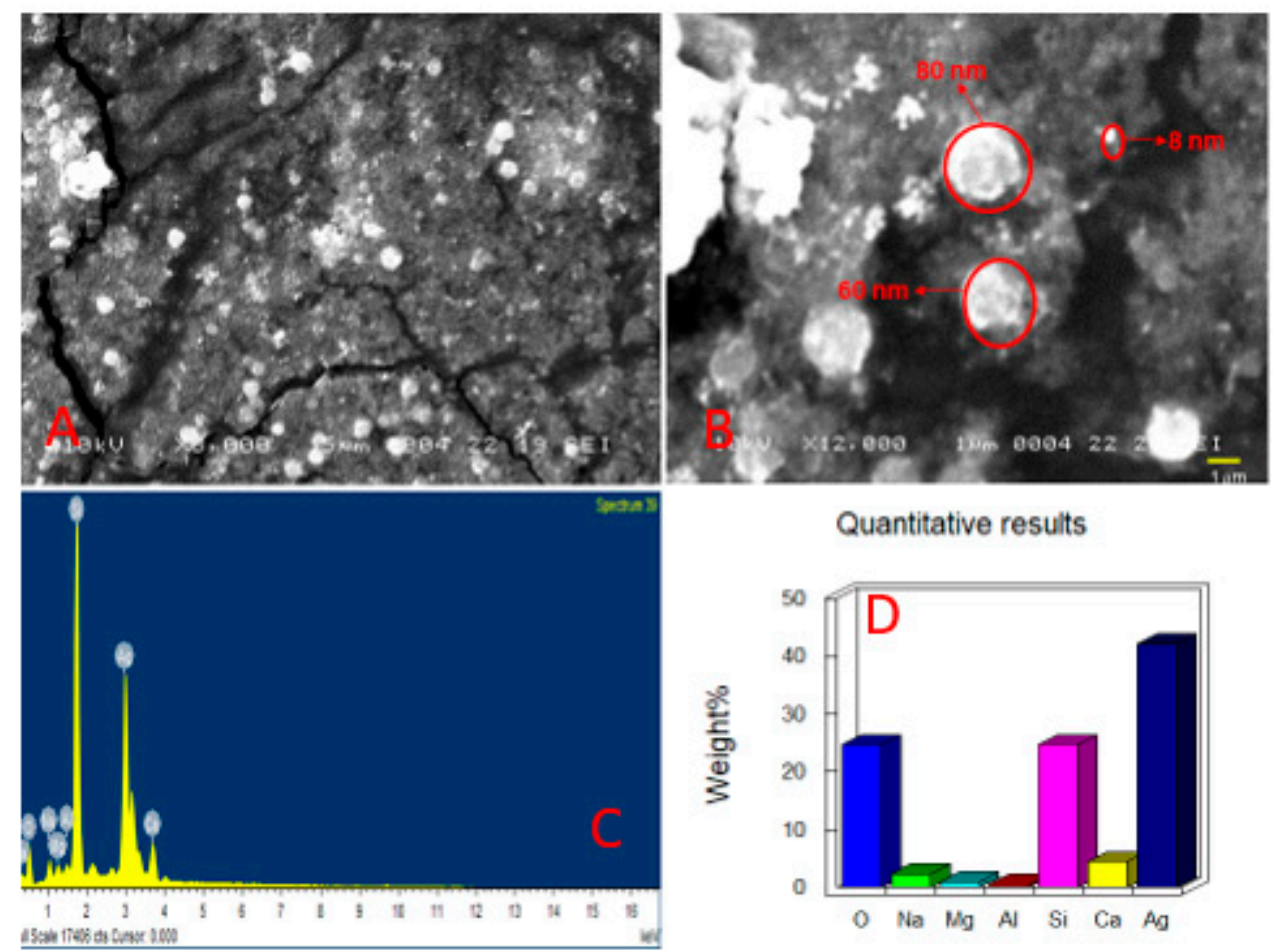

Figure 3. SEM and EDX images of synthesized AgNPs. (A,B) SEM micrograph of AgNPs at lower (X3000), and higher magnification (X12000), (C,D) represent EDX images and weight \% of elements. 


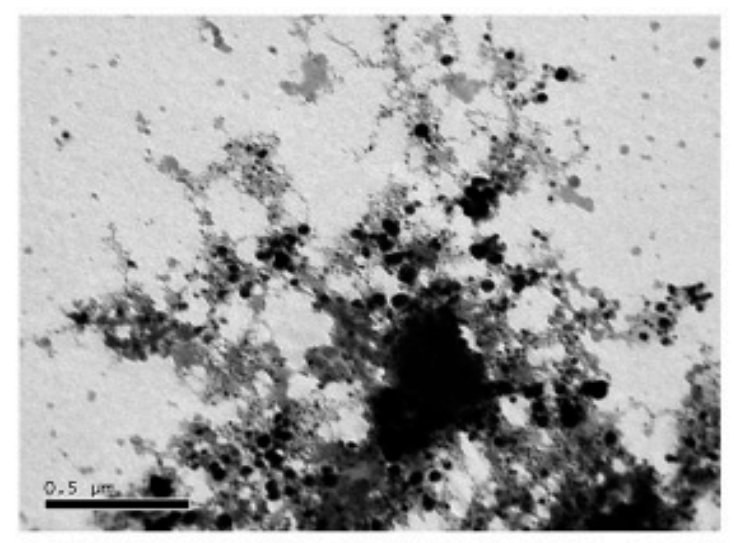

A

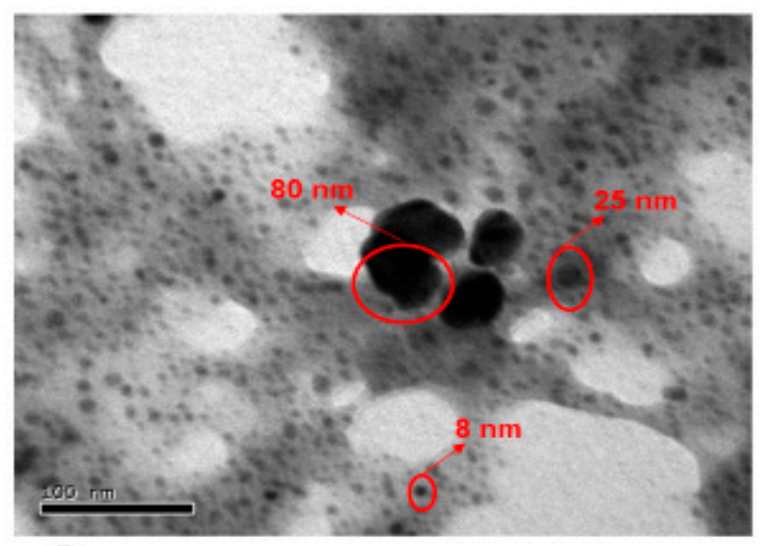

B

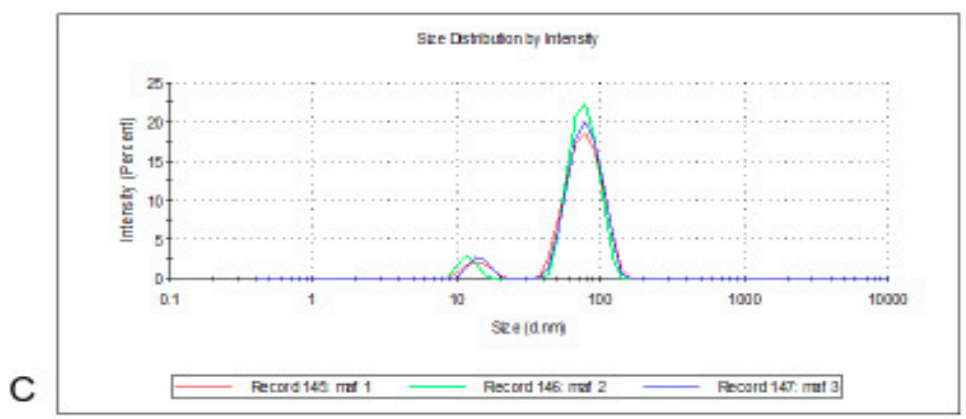

Figure 4. TEM images of Ns-AgNPs scale bar correspond to $0.5 \mu \mathrm{m}$ (A) $100 \mathrm{~nm}$ (B) particle size distribution by DLS (C).

\subsection{Assessment of MIC and MBC Activity}

Initially, the effect of Ns-AgNps was investigated against E. coli, K. pneumonia, P. aeruginosa, S. aureus and E. faecalis bacterialstrains. Ns-AgNps showed the significant bacteriostatic and bactericidal activity. Even the lowest concentration of Ns-AgNps restricted the highest rate of inhibition against S. aureus (6.5 and $15 \mu \mathrm{g} / \mathrm{mL}$ ) and E. faecalis $(6.5$ and $15 \mu \mathrm{g} / \mathrm{mL})$. Antimicrobial activity of S. aureus and E. fecalis was more pronounced than E. coli (15 and $30 \mu \mathrm{g} / \mathrm{mL}$ ), K. pneumonia (15 and $30 \mu \mathrm{g} / \mathrm{mL}$ ), and P. aeruginosa (30 and $60 \mu \mathrm{g} / \mathrm{mL}$ ) respectively (Table 1). In addition, Ns-AgNps concentration against above mentioned bacterial strains showed 6.5-30 $\mu \mathrm{g} / \mathrm{mL}$ concentration for MIC and MBC values were $15-60 \mu \mathrm{g} / \mathrm{mL}$. Our above-mentioned results revealed that Ns-AgNps exhibited excellent antibacterial activity and was in accordance with the findings of a previous study [35]. Silver nanoparticle play an important role in bactericidal, bacteriostatic and also kill the other types of pathogens. Sadeghi et al. evaluated the bactericidal effect of silver nanoparticles and chlorhexidine against S. mutans to observe that silver nanoparticles showed a statistically significant bactericidal effect as compared to chlorhexidine [36].

Table 1. Minimum inhibitory concentration (MIC) and minimum bactericidal concentration (MBC) activity of Ns-AgNps.

\begin{tabular}{cccc}
\hline \multirow{2}{*}{ S. No } & Bacterial Strains & \multicolumn{2}{c}{ Synthesized Ns-AgNps } \\
\cline { 3 - 4 } & & MIC $(\mu \mathrm{g} / \mathbf{m L})$ & MBC $(\mu \mathrm{g} / \mathbf{m L})$ \\
\hline 1 & Klebsiella pneumonia (MTCC 618) & 15 & 30 \\
2 & Pseudomonas aeruginosa (MTCC 1688) & 30 & 60 \\
3 & Escherichia coli (MTCC 40) & 15 & 30 \\
4 & Staphylococcus aureus (MTCC 3160) & 6.5 & 15 \\
5 & Enterococcus faecalis (MTCC 439) & 6.5 & 15 \\
\hline
\end{tabular}




\subsection{Anti-Biofilm Activity}

The results of tissue culture plate method demonstrated that antibiofilm activity of the biosynthesized AgNPs from N. sativa seed extract was $88.42 \%$ for E. faecalis, $84.92 \%$ for E. coli, $81.86 \%$ for K. pneumonia, and $82.84 \%$ for S. aureus, respectively at $12.5 \mu \mathrm{g} / \mathrm{mL}$, while with the same concentration, the biofilm formation was reduced by $49.9 \%$ in the case of $P$. aeruginosa (Figure 5). Moreover, the evidence for screening the biofilm inhibition in the presence of Ns-AgNPs is shown in Figure 6. These findings suggest that the uptake of the biosynthesised Ns-AgNPs could diminish the biofilm forming abilities of tested pathogens. Similar studies were documented as results of biofilm inhibition at $100 \mu \mathrm{g} / \mathrm{mL}$ AgNPs [37]. Moreover, another study based on anti-biofilm demonstrated that the AgNPs synthesized from Momordica charantia extract were exhibited improved anti-biofilm activity against E.faecalis and A. hydrophilia. Additionally, the antibiofilm activity of AgNPs was attributed to the diffusion through the biofilms imparting antimicrobial actions [38].

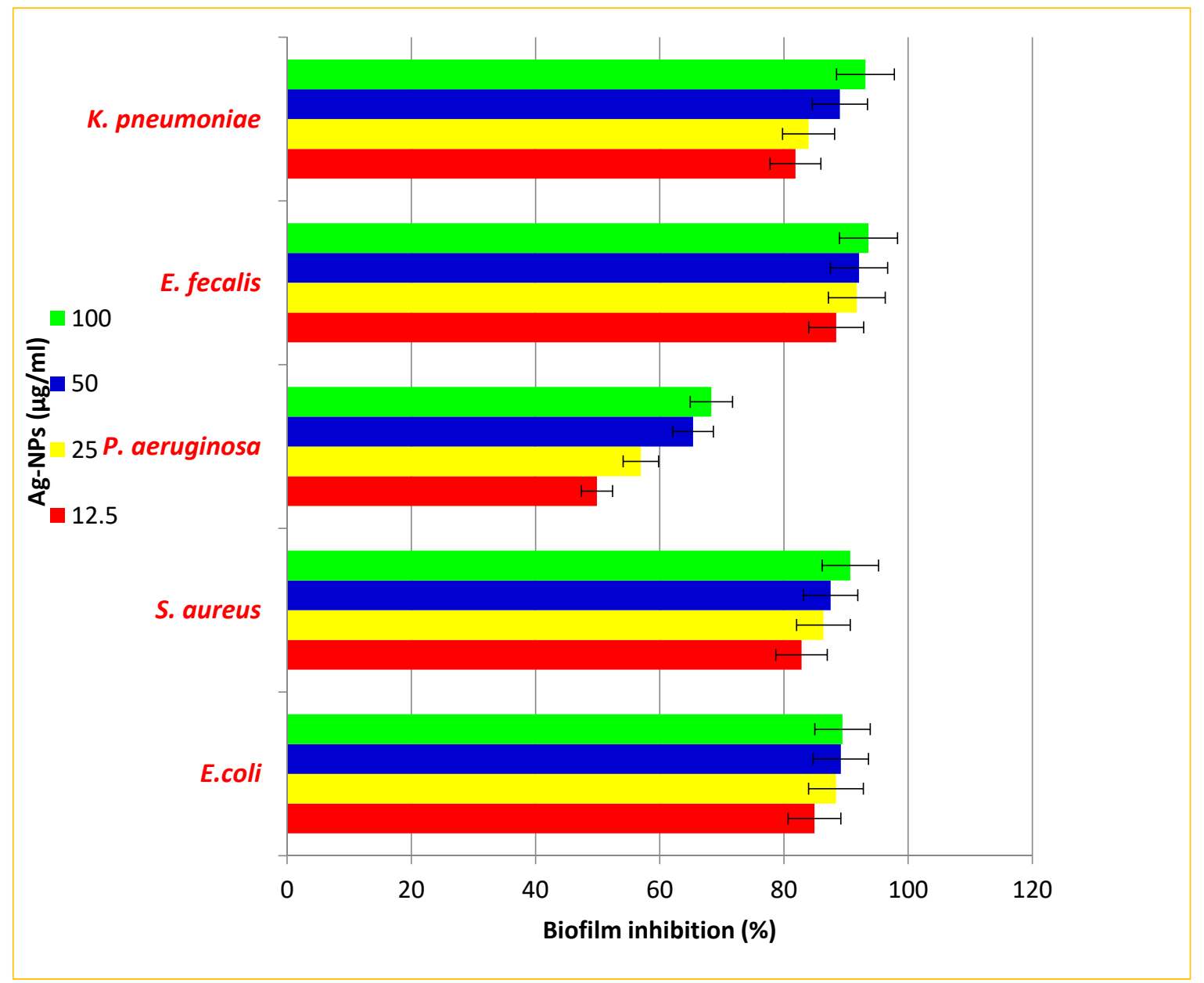

Figure 5. Anti-biofilm activity by using different concentrations $(12.5,25,50,100 \mu \mathrm{g} / \mathrm{mL})$ of silver nanoparticles synthesized from Black Seed extract against different standard bacterial strains. 


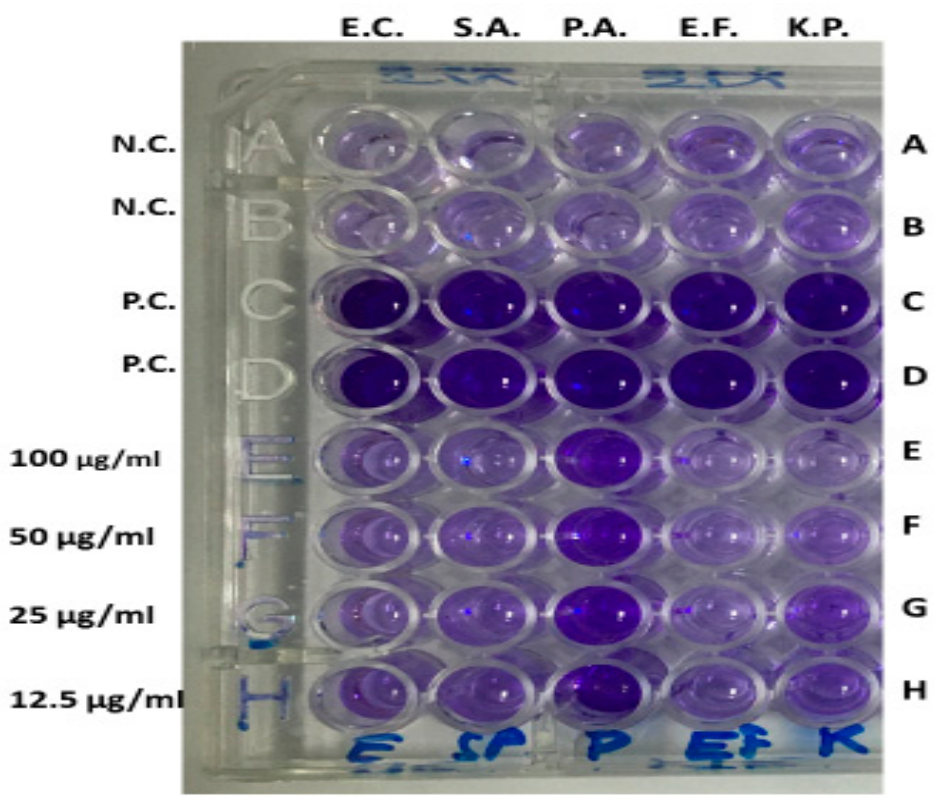

Figure 6. Image showing the screening of biofilm inhibition in the presence of Ns-AgNPs. Row A\&B-Negative control (N.C.): Culture media only, No bacterial colony and no Ns-AgNPs; Row C\&D-Positive control (P.C.): Culture media plus 5 different bacterial colonies in different wells accordingly and no Ns-AgNPs; Row $\mathbf{E}$ to $\mathbf{H}$-Culture media plus 5 different bacterial colonies in different wells accordingly and various concentrations (100 to $12.5 \mu \mathrm{g} / \mathrm{mL}$ ) of AgNPs synthesized from Nigella sativa extract. E.C.-E. coli; S.A.-S. aureus; P.A.-P. aeruginosa; E.F.-E. faecalis; K.A.-K. pneumoniae

\subsection{Effect of Ns-AgNPs Against Human (HCC712) Cell Lines}

The cytotoxic effect of Ns-AgNPs in the current study was examined against HCC712 (human breast cancer cells) using MTT assay. The toxicities were examined at different concentrations (25 to $200 \mu \mathrm{g} / \mathrm{mL}$ ) and compared to control. The percent inhibition of cell growth was increased with the concentration of the nanoparticles (Figure 7). The inhibition effect was time and dose dependent and the $\mathrm{IC}_{50}$ value of $150 \mu \mathrm{g} / \mathrm{mL}$ supports the levels of the inhibition.

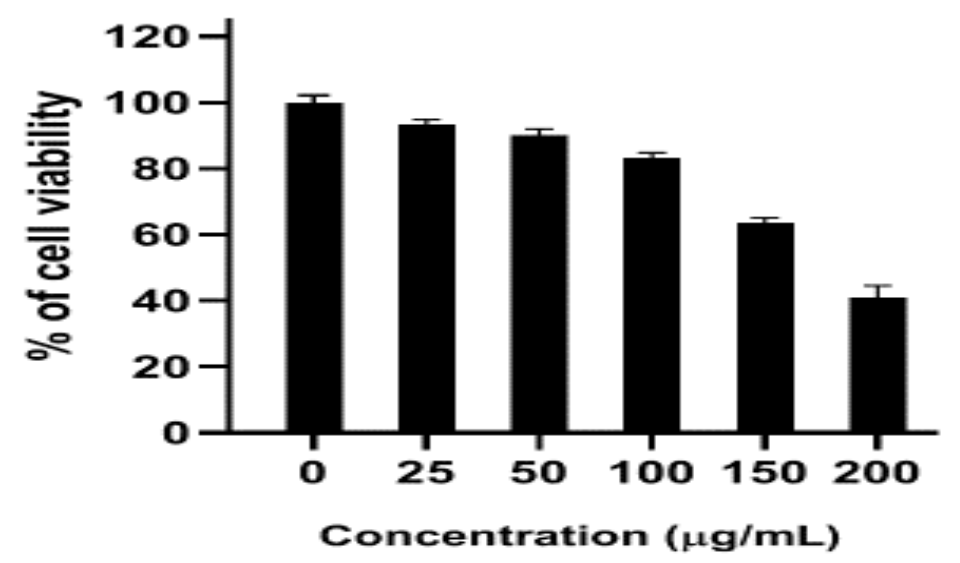

Figure 7. MTT assay results confirming the in-vitro cytotoxicity of the Ns-AgNPsagainst HCC 712 human breast cancer cell-lines.

It was observed that a high concentration of Ns-AgNPs showed promising activity against breast cancer cell lines and cell proliferation decreased after $24 \mathrm{~h}$. Moreover, findings exhibited that $150 \mu \mathrm{g} / \mathrm{mL}$ concentration of AgNPs is able to provoke the approximately $50 \%$ of cell mortality at different time intervals. The cell viability in the presence of AgNPs at different concentrations is illustrated in (Figure $8 \mathrm{~A}-\mathrm{F}$ ). The calculated IC50 value is approximately $175 \mu \mathrm{g} / \mathrm{mL}$ concentrations of Ns-AgNPs. 
Previously, similar findings were reported by Khateef et al. [39] in the form of a cytotoxicity effect in human breast cancer cells (MCF-7) against green synthesized AgNPs procured from Buchanania axillaris extracts. The morphological observation of the HCC712 cancer cells exhibited significant morphological changes and the cell density was decreased, which is a predictable mark of apoptotic cells (Figure 9).

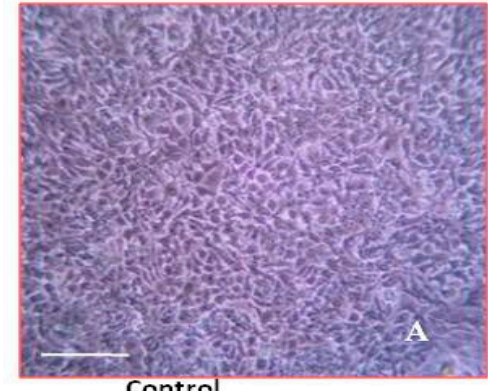

Control

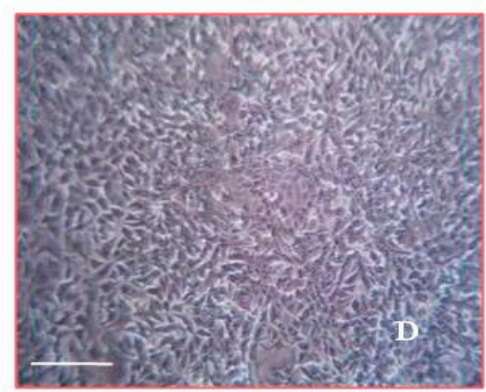

$100 \mu \mathrm{g} / \mathrm{ml}$

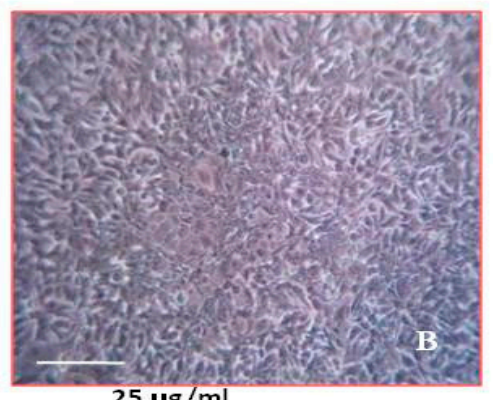

$25 \mu \mathrm{g} / \mathrm{ml}$

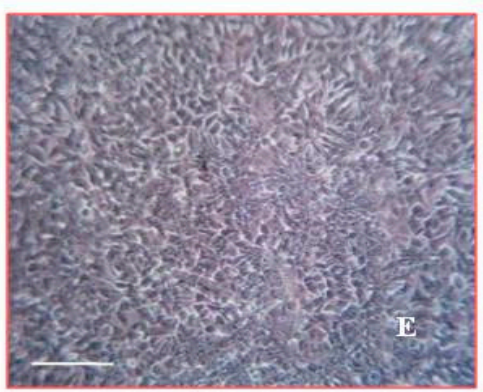

$150 \mu \mathrm{g} / \mathrm{ml}$
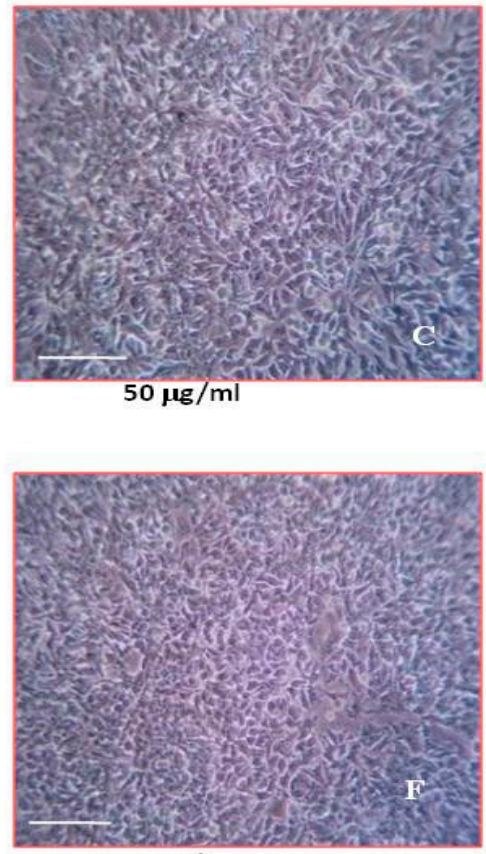

$200 \mu \mathrm{g} / \mathrm{ml}$

Figure 8. Morphology of the control and Ns-AgNPs treated HCC 712 human breast cancer cell-lines. Scale bar: $50 \mu \mathrm{m}$.

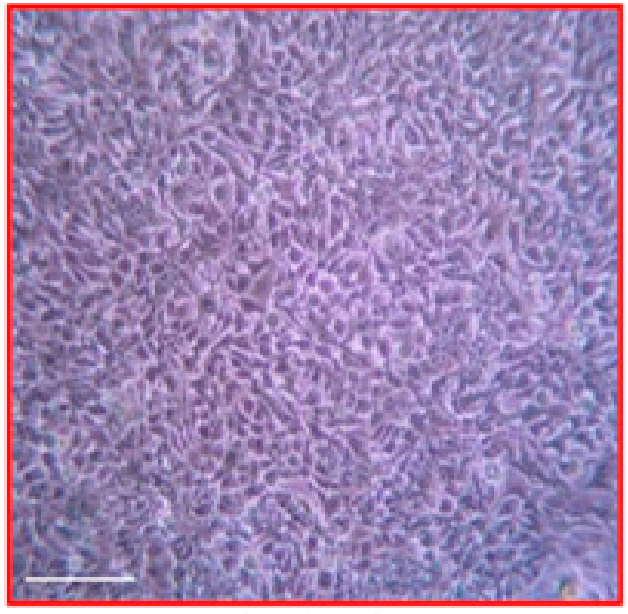

Control

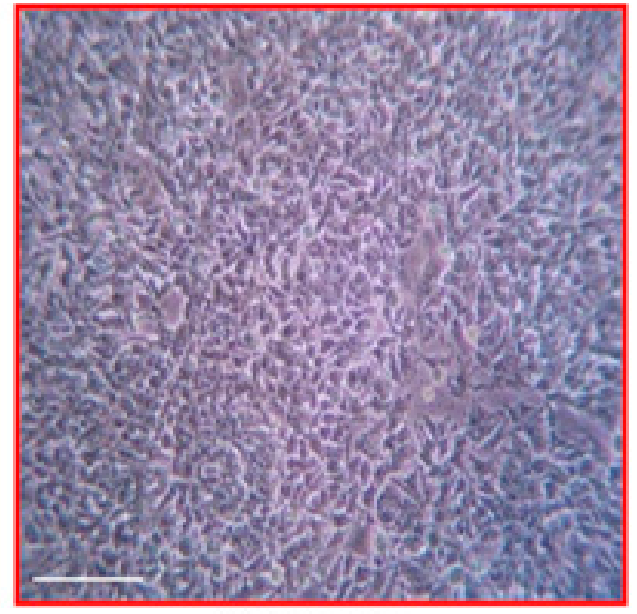

$200 \mu \mathrm{g} / \mathrm{ml}$

Figure 9. Morphology of control cells and $200 \mu \mathrm{g} / \mathrm{mL}$ silver nanoparticles treated HCC 712 human breast cancer cell-lines. Scale bar: $30 \mu \mathrm{m}$.

\section{Conclusions}

The study provides another example of an easy, non-toxic, and low cost, preparation of nanoparticles by Nigella sativa seed extract without any involvement of toxic chemical reducing agents. The biologically synthesized particles exhibited significant levels of activity such as an antimicrobial effect and the inhibition of biofilm formation against E. coli, K. pneumonia, P. aeruginosa, 
S. aureus, and E. faecalis. The current study findings revealed that Ns-AgNPs showed a significant cytotoxic effect on HCC712 breast cancer cell lines. In summary, our results a suggest cost-effective and eco-friendly approach for Ns-AgNps synthesis which may support the advancement of potential biomedical applications and alternative therapy involving the design of novel antibiofilm agents and multi drug resistance bacterial infection, and further could be developed as a template for other anti-cancer actions.

Author Contributions: A.A. design the conceptualized research study. H.K. and M.A. executed the detailed analysis and drafted manuscript F.K.A.K. and M.A.A. drafted manuscript. K.S.A. and A.H.R. given potential input in results interpretation. R.K. supervised the whole process. All authors have read and agreed to the published version of the manuscript.

Funding: This research work was financially supported by Deanship of scientific research grant, Qassim University, KSA. Grant number: 3970-cams1-2018-1-14-S.

Acknowledgments: Authors like to thanks to their respective institutions for sophisticated analytical instrumentation facilities. The authors acknowledge deanship of scientific research (DSR/grant number/year) Qassim University, kingdom of Saudi Arabia, providing finance support for research project fund.

Conflicts of Interest: The authors declare no conflict of interest.

Appendix A

\begin{tabular}{cc}
\hline Ns & Nigella sativa \\
AgNPs & Silver nanoparticles \\
DLS & Dynamic light scattering \\
UV-Vis & Ultraviolet visible \\
FTIR & Fourier-Transform Infrared Radiometer \\
SEM & Scanning light microscope \\
EDX & Energy dispersed X-ray \\
\hline
\end{tabular}

\section{References}

1. Naganathan, K.; Thirunavukkarasu, S. Green way genesis of silver nanoparticles using multiple fruit peels waste and its antimicrobial, anti-oxidant and anti-tumor cell line studies. In Conference Series: Materials Science and Engineering; IOP Publishing: Bristol, UK, 2017.

2. Choi, S.M.; Seo, M.H.; Kim, H.J.; Kim, W.B. Synthesis and characterization of graphene-supported metal nanoparticles by impregnation method with heat treatment in $\mathrm{H} 2$ atmosphere. Synth. Met. 2011, 161, 2405-2411. [CrossRef]

3. Das, G.; Patra, J.K.; Debnath, T.; Ansari, A.; Shin, H.-S. Investigation of antioxidant, antibacterial, antidiabetic, and cytotoxicity potential of silver nanoparticles synthesized using the outer peel extract of Ananas comosus (L.). PLoS ONE 2019, 14, e0220950. [CrossRef] [PubMed]

4. Erdogan, O.; Abbak, M.; Demirbolat, G.M.; Birtekocak, F.; Aksel, M.; Pasa, S.; Ozge, C. Green synthesis of silver nanoparticles via Cynara scolymus leaf extracts: The characterization, anticancer potential with photodynamic therapy in MCF7 cells. PLoS ONE 2019, 14, e0216496. [CrossRef] [PubMed]

5. Hamouda, R.A.; Hussein, M.H.; Abo-elmagd, R.A.; Bawazir, S.S. Synthesis and biological characterization of silver nanoparticles derived from the cyanobacterium Oscillatoria limnetica. Sci. Rep. 2019, 9, 13071. [CrossRef]

6. Afifa, Q.; Rajesh, K.; Anupam, D. Green synthesis of silver nanoparticles by seed of Phoenix sylvestris L. and their role in the management of cosmetics embarrassment. Green Chem. Lett. Rev. 2018, 11, 176-188.

7. Nayak, D.; Ashe, S.; Rauta, P.R.; Kumari, M.; Nayak, B. Bark extract mediated green synthesis of silver nanoparticles: Evaluation of antimicrobial activity and antiproliferative response against osteosarcoma. Mater. Sci. Eng. C 2016, 58, 44-52. [CrossRef]

8. Gao, X.; Yourick, J.J.; Topping, V.D.; Black, T.; Olejnik, N.; Keltner, Z. Toxicogenomic study in rat thymus of F1 generation offspring following maternal exposure to silver ion. Toxicol. Rep. 2015, 2, 341-350. [CrossRef]

9. Mah, T.F.C.; O'Toole, G.A. Mechanisms of biofilm resistance to antimicrobial agents. Trends Microbiol. 2001, 9, 34-39. [CrossRef] 
10. Sihorkar, V.; Vyas, S.P. Biofilm consortia on biomedical and biological surfaces: Delivery and targeting strategies reference style. Pharm. Res. 2001, 18, 1247-1254. [CrossRef]

11. Ansari, M.A.; Khan, H.M.; Khan, A.A.; Cameotra, S.S.; Alzohairy, M.A. Anti-biofilm efficacy of silver nanoparticles against MRSA and MRSE isolated from wounds in a tertiary care hospital. Indian J. Med. Microbiol. 2015, 33, 101-109. [CrossRef]

12. Kohler, B.; Sherman, R.; Howlader, N.; Jemal, A.; Ryerson, B.; Henry, K. Annual Report to the Nation on the Status of Cancer, 1975-2011, Featuring Incidence of Breast Cancer Subtypes by Race/Ethnicity, Poverty, and State. J. Natl. Cancer Inst. 2015, 30, 107. [CrossRef] [PubMed]

13. Xu, H.; Yao, L.; Sun, H.; Wu, Y. Chemical composition and antitumor activity of different polysaccharides from the roots of Actinidia eriantha. Carbohydr. Polym. 2009, 78, 316-322. [CrossRef]

14. Gottesman, M.M.; Fojo, T.; Bates, S.E. Multidrug resistance in cancer: Role of ATP-dependent transporters. Nat. Rev. Cancer. 2002, 2, 48-58. [CrossRef] [PubMed]

15. Husseiny, S.M.; Salah, T.A.; Anter, H.A. Biosynthesis of size controlled silver nanoparticles by Fusarium oxysporum, their antibacterial and antitumor activities. J. Basic Appl. Sci. 2015, 4, 225-231. [CrossRef]

16. Khare, C.P. Encyclopedia of Indian Medicinal Plants; Springes-Verlag: Heidelberg, Germany; New York, NY, USA, 2004.

17. Mazahari, Y.; Torbati, M.; Azadmard, D.S.; Savage, G.P. A comprehensive review of the physicochemical, quality and nutritional properties of Nigella sativaoil. Food Rev. Int. 2019, 35, 342-362. [CrossRef]

18. Kuppusamy, P.; Yusoff, M.M.; Maniam, G.P.; Govindan, N. Biosynthesis of metallic nanoparticles using plant derivatives and their new avenues in pharmacological applications-An updated report. Saudi Pharm. J. 2016, 24, 473-484. [CrossRef]

19. Ansari, M.A.; Alzohairy, M.A. One-pot facile green synthesis of silver nanoparticles using seed extract of Phoenix dactylifera and their bactericidal potential against MRSA. Evid.-Based Complement. Altern. Med. 2018. [CrossRef]

20. Balasamy, R.J.; Ravinayagam, V.; Alomari, M.; Ansari, M.A.; Almofty, S.A.; Rehman, S.; Dafalla, H.; Marimuthu, P.R.; Akhtar, S.; Al Hamad, M. Cisplatin delivery, anticancer and antibacterial properties of Fe/SBA-16/ZIF-8 nanocomposite. RSC Adv. 2019, 9, 42395-42408. [CrossRef]

21. Lewis, K. Riddle of biofilm resistance. Antimicrob. Agents Chemother. 2001, 45, 999-1007. [CrossRef]

22. Ashour, A.A.; Raafat, D.; El-Gowelli, H.M.; El-Kamel, A.H. Green synthesis of silver nanoparticles using cranberry powder aqueous extract: Characterization and antimicrobial properties. Int. J. Nanomed. 2015, 10, 7207-7221.

23. Preetha, D.; Prachi, K.; Chirom, A.; Arun, R. Synthesis and Characterization of Silver Nanoparticles Using Cannonball Leaves and Their Cytotoxic Activity against MCF-7 Cell Line. J. Nanotechnol. 2013, 5, 598328.

24. Ranjan, P.; Das, M.P.; Kumar, M.S.; Anbarasi, P.; Sindhu, S.; Sagadevan, E.; Arumugam, P. Green synthesis and Characterization of Silver nanoparticles from Nigella sativa and its application against UTI causing Bacteria. J. Acad. Ind. Res. 2013, 2, 145-149.

25. Jyoti, M.; Baunthiyal, M.; Singh, A. Characterization of silver nanoparticles synthesized using Urticadioica Linn leaves and their synergistic effects with antibiotics. J. Radiat. Res. Appl. Sci. 2016, 9, 217-227. [CrossRef]

26. Dada, A.O.; Ojediran, O.J.; Dada, F.E.; Olalekan, A.P.; Awakan, O.J. Green synthesis and characterization of silver nanoparticles using Calotropis procera extract. J. Appl. Chem. Sci. Int. 2017, 8, 137-143.

27. Von White, G.; Kerscher, P.; Brown, R.M.; Morella, J.D.; McAllister, W.; Dean, D.; Kitchens, C.L. Green synthesis of robust, biocompatible silver nanoparticles using garlic extract. J. Nanomater. 2012, 55. [CrossRef] [PubMed]

28. Ponarulselvam, S.; Panneerselvam, C.; Murugan, K. Synthesis of silver nanoparticles using leaves of Catharanthus roseus Linn. G. Don and their antiplasmodial activities. Asian Pac. J. Trop. 2012, 2, 574-580. [CrossRef]

29. Sondi, I.; Salopek-Sondi, B. Silver nanoparticles as antimicrobial agent: A case study on E. coli as a model for Gram-negative bacteria. J. Colloid Interface Sci. 2004, 275, 177-182. [CrossRef]

30. Kasthuri, J.; Veerapandian, S.; Rajendiran, N. Biological synthesis of silver and gold nanoparticles using apiin as reducing agent. Colloids Surf. B Biointerfaces 2009, 68, 55-60. [CrossRef]

31. Otunola, G.A.; Afolayan, A.J.; Ajayi, E.O. Characterization, antibacterial and antioxidant properties of silver nanoparticles synthesized from aqueous extracts of Allium sativum, Zingiber officinale and Capsicum frutensces. Pharmacogn. Mag. 2017, 13, 201-208. [CrossRef] 
32. Dudkiewicz, A.; Tiede, K.; Loeschner, K.; Jensen, L.H.; Jensen, E.; Wierzbicki, R. Characterization of nanomaterials in food by electron microscopy. Trends Analyt. Chem. 2011, 30, 28-43. [CrossRef]

33. Bar, H.; Bhui, D.; Sahoo, G.P.; Sarkar, P.S.; Pyne, A.M. Green synthesis of silver nanoparticles using seed extract of Jatropha curcas, Colloids Surf. A Physicochem. Eng. 2009, 348, 212-216. [CrossRef]

34. Saber, M.M.; Mirtajani, S.B.; Karimzadeh, K. Green synthesis of silver nanoparticles using Trapa natans extract and their anticancer activity against A431 human skin cancer cells. J. Drug Deliv. Sci. Technol. 2018, 47, 375-379. [CrossRef]

35. Singh, P.; Pandit, S.; Garnæs, J.; Tunjic, S.; Mokkapati, V.R.S.S.; Sultan, A.; Thygesen, A.; Mackevica, A.; Mateiu, R.V.; Daugaard, A.E.; et al. Green synthesis of gold and silver nanoparticles from Cannabis sativa (industrial hemp) and their capacity for biofilm inhibition. Int. J. Nanomed. 2018, 13, 3571-3591. [CrossRef] [PubMed]

36. Sadeghi, R.; Olia, P.; Rezvani, M.B.; Taleghani, F.; Sharif, F. Comparison of the nanosilver and chlorhexidine antimicrobial effect on Streptococcus sanguis and actinomicosis viscosus. J. Islamic Dent. Assoc. 2010, 23, 225-231.

37. Kalishwaralal, K.; BarathManiKanth, S.; Pandian, S.R.; Deepak, V.; Gurunathan, S. Silver nanoparticles impede the biofi $1 \mathrm{~m}$ formation by Pseudomonas aeruginosa and Staphylococcus epidermidis. Colloids Surf. B 2010, 79, 340-344. [CrossRef]

38. Malaikozhundan, B.; Vaseeharan, S.; Vijayakumar, R.; Sudhakaran, N.; Gobi, G.; Shanthini, G. Antibacterial and antibiofilm assessment of Momordica charantia fruit extract coated silver nanoparticle. Biocatal. Aric. Biotechnol. 2016, 8, 189-196. [CrossRef]

39. Khateef, R.; Khadri, H.; Almatroudi, A.; Alsuhaibani, S.A.; Mobeen, S.A.; Khan, R.A. Potential in-vitro anti-breast cancer activity of green-synthesized silver nanoparticles preparation against human MCF-7 cell-lines. Adv. Nat. Sci. Nanosci. Nanotechnol. 2019, 10, 045012. [CrossRef]

(C) 2020 by the authors. Licensee MDPI, Basel, Switzerland. This article is an open access article distributed under the terms and conditions of the Creative Commons Attribution (CC BY) license (http://creativecommons.org/licenses/by/4.0/). 